\title{
Ecological responses of periphyton dry mass and epilithic diatom community structure for different atrazine and temperature scenarios
}

\author{
Adroit Takudzwa Chakandinakira*1 ${ }^{* 1}$ Tongayi Mwedzi ${ }^{2}$, Tawanda Tarakini ${ }^{2}$ and Taurai Bere ${ }^{3}$ \\ 'Department of Geography, Bindura University of Science Education, P. Bag 1020, Bindura, Zimbabwe \\ ${ }^{3}$ Department of Wildlife Ecology and Conservation, Chinhoyi University of Technology, Off Harare-Chirundu Rd, P Bag 7724, Chinhoyi, Zimbabwe \\ ${ }^{2}$ Department of Freshwater and Fishery Sciences, Chinhoyi University of Technology, Off Harare-Chirundu Rd, PBag 7724, Chinhoyi, Zimbabwe
}

\begin{abstract}
Climate change-induced temperature increase may influence the ecotoxicity of agricultural herbicides such as atrazine and consequently negatively impact aquatic biota. The objective of this study was to assess the effects of increased temperature on the ecotoxicity of atrazine to diatom community structure and stream periphyton load using laboratory microcosm experiments. A natural periphyton community from the Mukwadzi River, Zimbabwe, was inoculated into nine experimental systems containing clean glass substrates for periphyton colonisation. Communities were exposed to $0 \mu \mathrm{g} \cdot \mathrm{L}^{-1}$ (control), 15 $\mu \mathrm{g} \cdot \mathrm{L}^{-1}$ and $200 \mu \mathrm{g} \cdot \mathrm{L}^{-1}$ atrazine concentrations at 3 temperature levels of $26^{\circ} \mathrm{C}, 28^{\circ} \mathrm{C}$ and $30^{\circ} \mathrm{C}$. Periphyton dry weight and community taxonomic composition were analysed on samples collected after 1, 2 and 3 weeks of colonisation. A linear mixedeffects model was used to analyse the main and interactive effects of atrazine and temperature on dry mass, species diversity, evenness and richness. Temperature and atrazine had significant additive effects on species diversity, richness and dry mass. As temperature increased, diatom species composition shifted from heat-sensitive species such as Achnanthidium affine to heat-tolerant species such as Achnanthidium exiguum and Epithemia adnata. Increasing temperature in aquatic environments contaminated with atrazine results in sensitive and temperature-intolerant diatoms being eliminated from periphyton communities. Climate change will exacerbate effects of atrazine on periphyton dry mass and diatom community structure.
\end{abstract}

Keywords: ecotoxicology, microcosm, biomonitoring, climate change

\section{INTRODUCTION}

The increase in agricultural activity and shift from traditional to chemical means of weed control has caused an increase in the contamination of water bodies by herbicides, consequently threatening aquatic biodiversity (Relyea, 2005). Increased use of agricultural herbicides such as atrazine has led to pollution of water bodies, thus leading to degradation of water quality (Villeneuve et al., 2011). Atrazine (2-chloro-4- (ethylamino)6-s-triazine) is a triazine herbicide that inhibits photosynthesis through inhibiting electron transfer from photosystem II (PS II) by competing with the electron carrier molecule, plastoquinone (Shimabukuro and Swanson, 1969). Atrazine is mainly used for the control of annual broadleaf and grass weeds in agricultural production of maize. While atrazine has been banned in Europe, it is still widely used in other regions such as North America and Africa (Bethsass and Colangelo, 2006).

Periphyton communities (diatoms in particular) are good indicators of both climate change and water quality as they have highly resolved temporal sensitivity because of their short generation time and high sensitivity to nutrient input, organic pollution and chemical pollutants (Kilham et al., 1996; Bere and Chakandinakira, 2018). The response of periphyton to PS II inhibitors, such as atrazine, differs depending on the species, the effective herbicide concentration and the physiological state of algae (Guasch et al., 1998). Periphyton are confronted with anthropogenic-induced chemical stressors such as herbicides (Villeneuve et al., 2011) and physical stressors such as increased water temperature (Mahdy et al., 2015). Selection pressure (environmental conditions) may therefore result in susceptible diatom species being replaced by more resistant ones, thus

${ }^{*}$ Corresponding author, email: chakandinakirat@gmail.com Received 22 May 2018; accepted in revised form 20 September 2019 affecting community structure as there would be reduced growth in other sensitive species (Blanck, 2002; Wood et al., 2016).

The toxicity of herbicides on periphyton in tropical regions is unknown as ecotoxicological testing is almost exclusively conducted in the temperate regions where water temperature ranges between $15^{\circ} \mathrm{C}$ and $24^{\circ} \mathrm{C}$ (Daam and Van Den Brink, 2010). Water temperatures as high as $28^{\circ} \mathrm{C}$ have been recorded in tropical rivers (Dallas, 2008) and, with the advent of climate change, higher temperatures are expected (Beilfuss, 2012). Projected increases in average annual temperatures for Southern Africa range from $1-4^{\circ} \mathrm{C}$ by 2050 (Daron, 2014). Although research on the interaction of temperature and atrazine has been conducted in temperate regions, applicability of the results could differ because of different climatic conditions (Baxter et al., 2016). For example, Zimbabwe's continental interior location means that it is predicted to warm even more rapidly than the global average (Ministry of Environment and Natural Resources Management, 2013). This potentially increases the interactive effect of temperature and atrazine.

It is expected that the use of pesticides will increase concomitantly with expected temperature changes, as warmer climates and climate extremes could be more favourable to the proliferation of insect and plant pests, and plant diseases (Kibria, 2014). Further to this, temperature is understood to have effects on the toxicity of pollutants including the persistent ones like atrazine. Previous studies have documented effects of increases in atrazine toxicity to catfish with temperature increase (Gaunt and Barker, 2000); lethality of the persistent organic pollutant dieldrin to the freshwater darter (Etheostoma nigrum) increased with increasing temperatures (Silbergeld, 1973); increase in mortality in juvenile rainbow trout exposed to the insecticide endosulfan as temperature was increased from $13^{\circ} \mathrm{C}$ to $16^{\circ} \mathrm{C}$ (Capkin et al., 2006); and toxicity of the insecticide carbaryl to the green frog increased with an increase in temperature 
(Boone and Bridges, 1999), among others (Lydy et al., 1999; Broomhall, 2002; Kibria, 2014; Landis et al., 2014). Vapouration of herbicides has been reported to be greater under tropical compared to temperate climates (Daam and Van Den Brink, 2010). The warmer climate also gives rise to faster breakdown of herbicide molecules in accordance with basic chemical reaction principles. The implications of these climate-induced changes on associated biota remain unknown (Bozinovic and Pörtner, 2015; Baxter et al., 2016). Quantifying such implications will help address water quality problems associated with the effect of climate change on the toxicity of aquatic pollutants. Such information should be available to increase adaptive capacity, thus reducing vulnerability where water management is concerned. More specifically, the effects of climate change on the toxicity of atrazine need to be quantified to implement informed conservation measures.

The cause-effect relationship, chain reactions and interactions between stressors and biota should be well understood for effective management of aquatic systems (Bere and Tundisi, 2011). These can be understood and interpreted using two hypotheses: (i) climate-induced toxicant sensitivity (CITS) hypothesis (Kimberly and Salice, 2014), where acclimation to altered climate parameters increases toxicant sensitivity, or (ii) toxicant-induced climate susceptibility (TICS), where toxicant exposure increases vulnerability to subsequent changes in climatic conditions (Hooper et al., 2013). This study employs microcosm experiments to explore the climate-induced toxicant sensitivity hypothesis for natural periphyton communities from tropical streams.

The aim of this study was to test the main and interactive effects of temperature and atrazine concentration on stream periphyton dry mass and epilithic diatom composition and community structure (diversity, evenness and richness). We endeavoured to explore: (i) the effect of different temperature scenarios on stream periphyton dry mass and epilithic diatom composition and community structure; (ii) the effect of atrazine on stream periphyton dry mass and epilithic diatom composition and community structure; and (iii) the interactive effect of different levels of temperature and atrazine on stream periphyton dry mass and epilithic diatom composition and community structure. We hypothesized that increases in temperature will result in an increase in the toxicity of atrazine by increasing the sensitivity of periphyton to atrazine and hence affect periphyton dry mass and epilithic diatom community structure and composition.

\section{MATERIALS AND METHODS}

\section{Field periphyton collection}

Periphyton were collected from the Mukwadzi River near Mapinga, Zimbabwe $\left(17^{0} 26.369^{\prime} \mathrm{E}\right.$; $\left.030^{\circ} 37.195^{\prime} \mathrm{S}\right)$. Water temperature in the river ranged from $19.3 \pm 4.5^{\circ} \mathrm{C}$ to 23.3 $\pm 3.7^{\circ} \mathrm{C}$ from January to August 2012 (Bere and Mangadze, 2014). The site water was tested for atrazine using liquidliquid extraction (Yokley and Cheung, 2000) (Thermo Fisher Scientific, Waltham, MA, USA) and no trace of atrazine was found. Periphyton was sampled by scrubbing stones with a toothbrush in May 2016. Before sampling, the stones were gently shaken in the stream to remove loosely attached sediments and non-epilithic diatoms. The resulting biofilm suspension, making up a total of approximately $15 \mathrm{~L}$, was pooled to form one sample that was put in plastic bottles. The biofilm suspension was then transported to the laboratory in a portable ice chest at the site water temperature where it was inoculated in the systems described in the section below.

\section{Experimental setup and design}

Experimental systems were set up to allow exposure of periphyton to stressors under controlled conditions in a laboratory. The experiment was conducted in the hot dry season (10-31 May 2016). A total of 9 microcosm experimental units (EUs) were established (Fig. 1a) following Bere and Tundisi (2011). Each EU consisted of 3 artificial streams made up of half-polyvinyl chloride (PVC) tubes measuring $90 \times 14 \times 8 \mathrm{~cm}$ that were connected in parallel to a $50 \mathrm{~L}$ tank (Bere and Tundisi, 2011). All systems were filled with Woods Hole culture medium prepared from distilled water (Nichols, 1973), modified by diluting 4 times, after Gold et al. (2003). This culture medium was kept without ethylenediaminetetraacetic acid (EDTA), which presents very high binding capacities for metals (Stauber and Florence, 1989), and supplemented with silica, an essential nutrient for diatom growth (Gold et al., 2003). A submersible pump (Aqua One P.R.C, Australia) allowed the continuous flow of water through each system at $10 \mathrm{~mL} \cdot \mathrm{s}^{-1}$, corresponding to a velocity of $0.2 \mathrm{~cm} \cdot \mathrm{s}^{-1}$

Each stream was fitted with 6 glass substrates $(10 \times 5 \mathrm{~cm})$ in a slightly slanting position for periphyton colonization (Fig. 1a). Water level was kept at $0.5 \mathrm{~cm}$ above the highest end of the glass substrate. A light intensity of $55 \pm 5 \mu \mathrm{mol} \cdot \mathrm{s}^{-1} \cdot \mathrm{m}^{-2}$ (falling in the range recommended by the international guidelines for ecotoxicological tests) (Nyholm and Källqvist, 1989; Laviale et al., 2010) at the water-air interface for photosynthetically active radiation $(400-700 \mathrm{~nm})$ was provided by fluorescent tubes with a light:dark regime of 12:12 h and measured using a Milwaukee Model SM700 light meter. In each EU, the required temperature was maintained by a submergible thermostat aquarium water heater (Via Aqua Commodity Inc., China) and measured using a thermometer after 1, 2 and 3 weeks. The systems were equilibrated overnight before the addition of epilithic diatom inoculum and atrazine (Detenbeck et al., 1996).

\section{Atrazine exposure}

Homogenised periphyton suspension from the field site was divided into 9 equal volumes of approximately $1.6 \mathrm{~L}$ corresponding to the number of EUs (control, low and high atrazine levels under 3 different temperature regimes). The schematic representation of the atrazine and temperature exposures used in this study is shown in Fig. 1b. Technical grade atrazine 500 , with $47 \%$ atrazine, $3 \%$ other triazine and $50 \%$ other inert ingredients, supplied by Agricura Private Limited, Zimbabwe, was used to prepare the stock solutions by mixing it with wood culture medium and making sure that the solution was clear with no particulates.

Periphytic inoculum, in equal volumes, was introduced to the already thermoregulated EUs (Lambert et al., 2016). Atrazine stock solution was added to each EU with colonised periphyton after $24 \mathrm{~h}$. Periphyton were exposed to $0 \mu \mathrm{g} \cdot \mathrm{L}^{-1}$ (control), $15 \mu \mathrm{g} \cdot \mathrm{L}^{-1}$ (low) and $200 \mu \mathrm{g} \cdot \mathrm{L}^{-1}$ (high) of atrazine under 3 temperature levels, $26^{\circ} \mathrm{C}(\mathrm{T} 1), 28^{\circ} \mathrm{C}(\mathrm{T} 2)$ and $30^{\circ} \mathrm{C}$ (T3), for 3 weeks. Previous studies have used atrazine exposures ranging from a few hours to many weeks, but most use 2-21 days (Guasch et al., 1998; Brain et al., 2012). Spiked water samples $\left(0,15,200 \mu \mathrm{g} \cdot \mathrm{L}^{-1}\right)$ were also analysed for determination of the actual atrazine concentrations, which were within $15 \%$ of the nominal values using a 


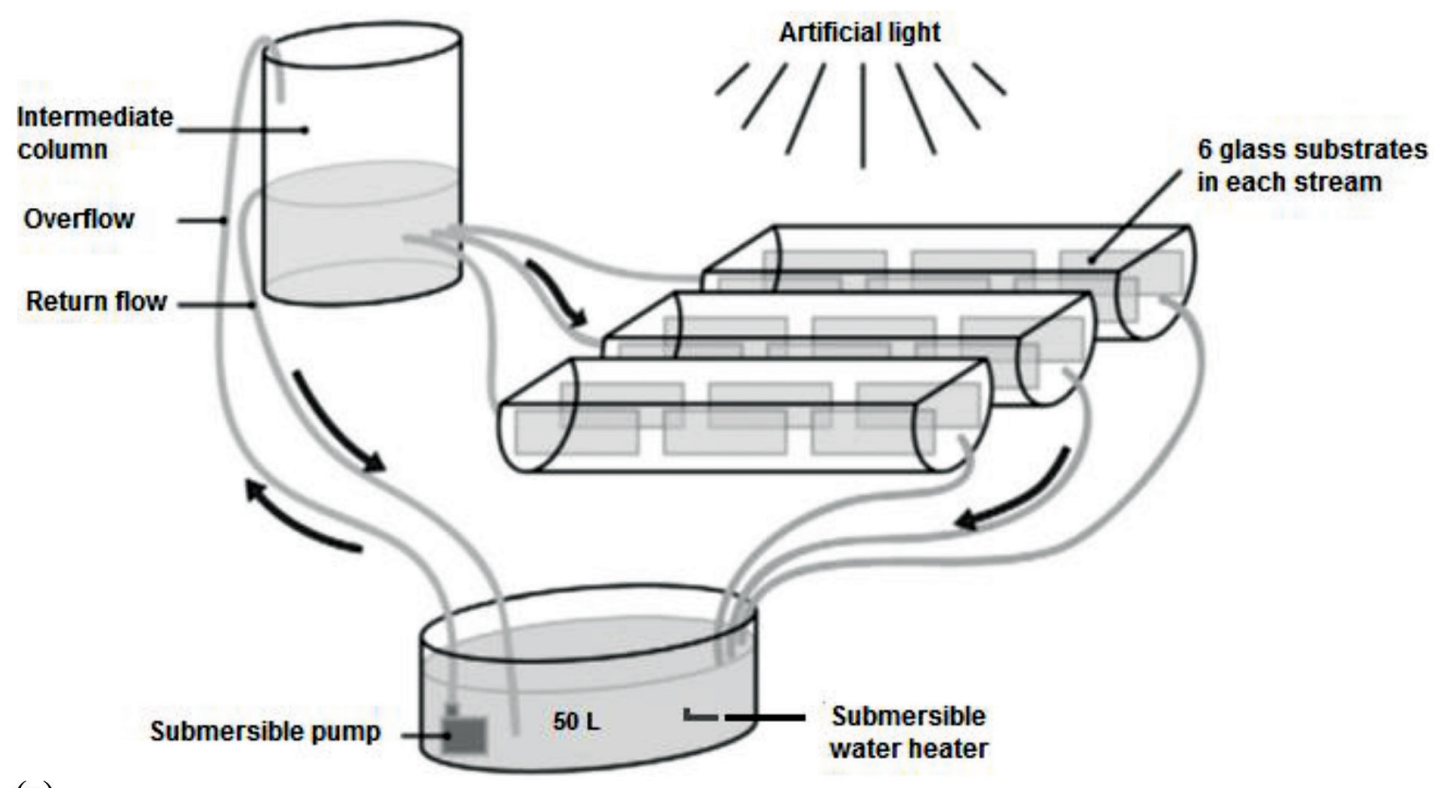

(a)

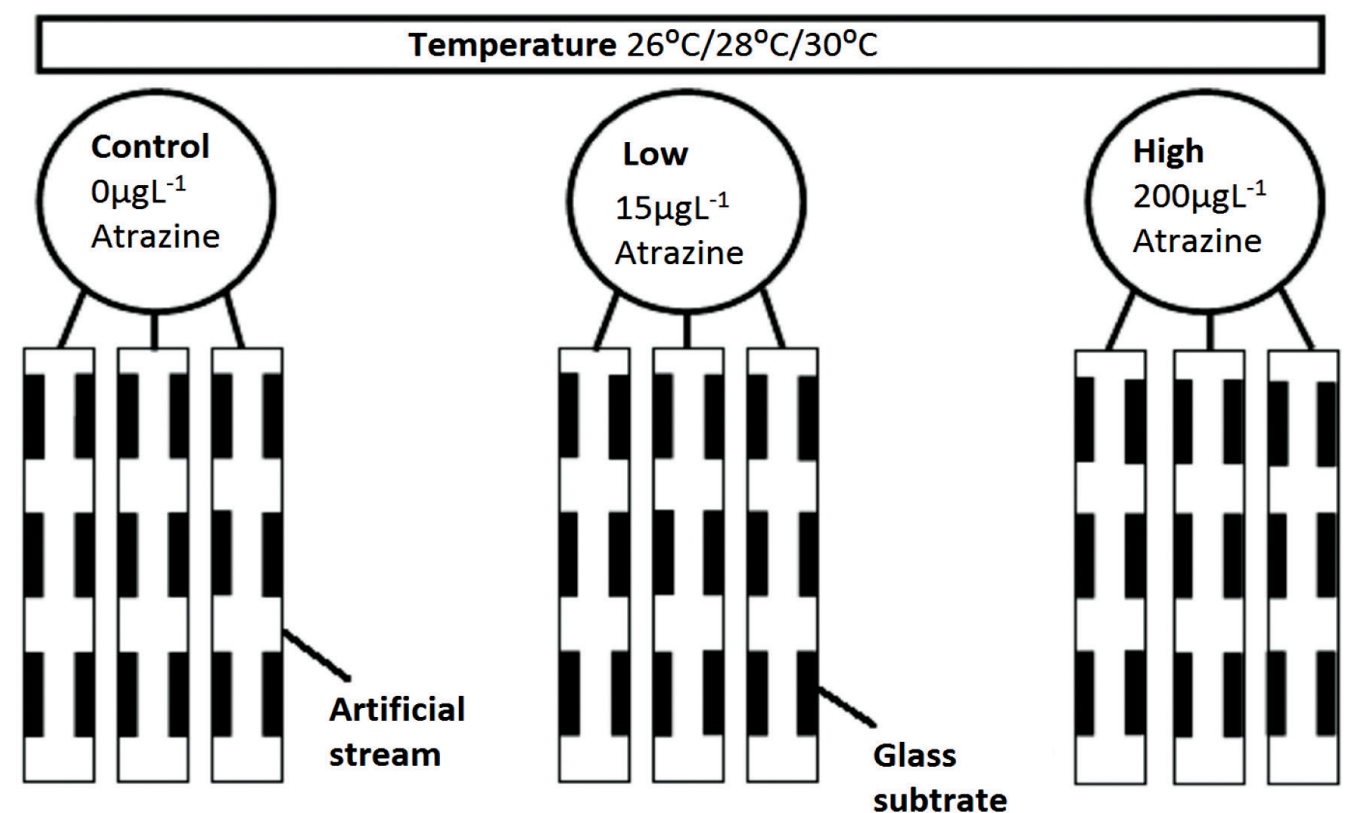

(b)

Figure 1. (a) Schematic representation of a closed experimental system used in this study adapted from Bere and Tundisi (2011); arrows indicate direction of water flow. (b) Schematic diagram of the experimental design

spectrophotometric method (Appendix, Table A1). The samples $(100 \mathrm{~mL})$ were extracted with two $10 \mathrm{~mL}$ portions of chloroform. The extract was then evaporated to dryness and the residue was dissolved in $25 \mathrm{~mL}$ of methanol. Aliquots were then analysed as described by Kesari and Gupta (1998). After every harvest (i.e. 1, 2 and 3 weeks after atrazine exposure), $10 \mathrm{~L}$ of stock solution were topped up in every EU to maintain a relatively constant exposure level and avoid nutrient depletion. There is little data on the concentration of atrazine in African water bodies, hence nominal concentrations were chosen as possible scenarios of herbicide concentration (Osibanjo et al., 2002). Intentionally high concentrations were selected in order to elicit a measurable response across all atrazine levels within the experimental duration.
Atrazine concentrations as high as $14.97 \mu \mathrm{g} \cdot \mathrm{L}^{-1}$ were recorded in South Africa in the early 1990s (Pick et al., 1992; Ansara-Ross et al., 2012). In the 1990s, mean atrazine levels in Zimbabwe were reported to be $2.5 \mu \mathrm{g} \cdot \mathrm{L}^{-1}$ and $97.7 \mu \mathrm{g} \cdot \mathrm{L}^{-1}$ for rivers and lakes, respectively (Osibanjo et al., 2002). Information on the current status of atrazine levels in aquatic systems in Zimbabwe was not available, but the levels could be higher than those recorded by Osibanjo et al. (2002) given the approximately 6 -fold increase in usage of herbicides for weed control in recent years (Mupako, Personal communication January 15, 2016). Other microcosm and artificial stream experiments have shown no effect of atrazine on periphyton at concentrations of up to $25 \mu \mathrm{g} \cdot \mathrm{L}^{-1}$ (Lynch et al., 1985), while in another experiment the first effect was seen at 130 to $180 \mu \mathrm{g} \cdot \mathrm{L}^{-1}$ (Jüttner et al., 
1995). Atrazine concentrations greater than $100 \mu \mathrm{g} \cdot \mathrm{L}^{-1}$ are considered to be high enough to cause dramatic effects on the photosynthesis, growth, chlorophyll content and biomass of most aquatic producers (Plumley and Davis, 1980; Kosinski and Merkle, 1984; Brockway et al., 1984; Wood et al., 2014). Thus, in this study, an atrazine level of $200 \mu \mathrm{g} \cdot \mathrm{L}^{-1}$ was used as the 'high' treatment. Duration of exposure in natural streams is expected to be prolonged with increased use of atrazine. Hansson (1992) reports water temperature ranges of $15^{\circ} \mathrm{C}$ to $24^{\circ} \mathrm{C}$ in the temperate regions. However, water temperatures as high as $29.8^{\circ} \mathrm{C}$ have been recorded in Lake Kariba, and of $26^{\circ} \mathrm{C}$ in the Manyame Catchment, with projections of $>30^{\circ} \mathrm{C}$ being expected by the middle of the $21^{\text {st }}$ century (Magadza, 2010; Bere and Mangadze, 2014). We therefore chose the high range of temperatures (i.e. $26^{\circ} \mathrm{C} \mathrm{C}, 28^{\circ} \mathrm{C}$ and $30^{\circ} \mathrm{C}$ ) to investigate plausible climate change scenarios in the tropics. The lowest temperature (i.e. $26^{\circ} \mathrm{C}$ ) was identical to the temperature of the sampling site and defined as the reference temperature, and 28 and $30^{\circ} \mathrm{C}$ were the two thermic stress levels tested. Microcosms typically lack the complexity of whole ecosystems, such that features such as air-water and sediment-water exchanges, as well as the activities of wide-ranging organisms are not included. However, they are important in understanding and separating underlying mechanisms and the system can be controlled experimentally in a way that the actual world cannot (Schindler, 1998). Microcosms mimic natural freshwater streams and enable investigators to examine responses to perturbations from external to internal sources at the level of an integrated ecosystem and they also allow replication (Odum, 1984; Crossland and La Point, 1992).

\section{Periphyton sampling and processing}

Biofilms were collected after being exposed to atrazine for a period of 1, 2 and 3 weeks from two random glass substrates per stream. Periphyton was brushed with a toothbrush into mineral water $(100 \mathrm{~mL})$. After each sampling time, the artificial substrates were reset with a new glass substrate to maintain identical flow conditions (Bere and Tundisi, 2012).

Periphyton suspensions were homogenised by gently shaking and divided into two fractions (50 mL each) for epilithic diatom taxonomy and dry mass analysis. For diatom taxonomy, the subsample was cleaned of organic material using concentrated sulphuric acid and further cleaned with hydrogen peroxide as an oxidizing agent following Biggs and Kilroy (2000). Subsamples of cleaned diatom suspensions were pipetted onto 3 replicate coverslips and allowed to dry before being permanently mounted to slides using Pleurax (1.73 refractive index and manufactured by Dr JC Taylor). A minimum of 250 diatom valves were identified on each slide (based on counting efficiency method by Pappas and Stoermer (1996)) and were identified to species level using the guide by Taylor et al. (2007). The light compound microscope, Nilcon, Alphaphot 2, Type YS2-H, China, was used for identification.

The second fraction of the sample was used to measure dry mass, expressed in $\mathrm{mg} \cdot \mathrm{cm}^{-2}$. The sample was dispensed on pre-weighed and labelled Whatman GF/C: $1.2 \mu \mathrm{m} 47 \mathrm{~mm}$ filter paper on a vacuum filtration unit. After filtration, the filter paper with the sample was oven-dried at $60^{\circ} \mathrm{C}$ for about $12 \mathrm{~h}$ until constant weight. This temperature is recommended to reduce the loss of some volatile organic compounds that can occur at higher temperatures (Aloi, 1990). The filter paper was reweighed to determine net dry weight mass of periphyton.

\section{Data analysis}

Principal component analysis (PCA) was used to show taxonomic differences in the different temperature and atrazine treatments using Paleontological Statistics (PAST) software Version 3.14 (Hammer et al., 2001). Taxa richness, Shannon Wiener diversity $\left(\mathrm{H}^{1}\right)$ and evenness metrics were also calculated in PAST. The effects of atrazine and temperature and their interaction on the different metrics and dry mass were tested by constructing linear mixed effects models (LMMs) while treating river identity nested in weeks as random variables using the 'Ime4' (Bates et al., 2011) package. To select appropriate models, full models were initially built having all independent variables (atrazine and temperature) and their interaction. The dredge function in package 'MuMIn' (Barton, 2009) was used in selecting the best model. For the LMMs and model selection, the R statistical software (Version 3.4.1) (R Core Team, 2016) was used. The residuals for the LMMs were checked for normality and normality assumptions were not significantly violated.

\section{RESULTS}

\section{Community composition}

A total of 106 diatom species belonging to 44 genera were recorded during the course of the study. Ten dominant diatom species with mean relative abundances greater than $3 \%$ (Mahdy et al., 2015), and present in at least 2 communities, were described as characteristic of each diatom community developed throughout the experiment.

A shift in species composition was observed as Brachysira wygaschii Lange-Bertalot was present only at the lower temperature treatment of $26^{\circ} \mathrm{C}$, while Staurosira elliptica (Schumann) Williams \& Round and Pseudostaurosira brevistriata (Grunow in Van Heurk) Williams \& Round appeared to be more temperature tolerant species as they were more prevalent in the higher temperature treatments of $28^{\circ} \mathrm{C}$ and $30^{\circ} \mathrm{C}$. As atrazine concentration increased across all temperature treatments, relative abundance of diatoms reduced (Appendix, Table A2).

Principal component analysis Axis 1 and Axis 2 accounted for $77.51 \%$ total variation of the diatom data, with the first axis accounting for $68.65 \%$. The principal component analysis separated diatom community structure mainly according to temperature treatment (Fig. 2). The $\mathrm{T} 1\left(26^{\circ} \mathrm{C}\right)$ temperature treatment, positively associated with the first axis, was associated with Fragilaria ulna (Nitzsch) Lange-Bertalot and Fragilaria biceps (Kutzing) Lange-Bertalot. The T2 $\left(28^{\circ} \mathrm{C}\right)$ treatment was negatively associated with the first and second axis and was characterised by species such as Rhopalodia gibberula (Ehrenberg) O Müller, Achnanthidium crassum (Hustedt) Potapova \& Ponader and Staurosira construens Ehrenberg. The $\mathrm{T} 3\left(30^{\circ} \mathrm{C}\right)$ treatments were negatively associated with Axis 1 and positively associated with Axis 2, being characterised by species such as Epithemia adnata (Kützing) Brébisson. PCA also clearly separated the diatom communities in relation to the different atrazine treatments. The control and low atrazine treatments were generally negatively associated with the second axis aggregating at the lower half of the PCA (which was also characterised by T1 and $\mathrm{T} 2$ temperature treatments). The high atrazine treatment was generally positively associated with Axis 2 being positioned at the top half of the PCA (which is also associated with the T3 temperature treatment) (Fig. 2). 


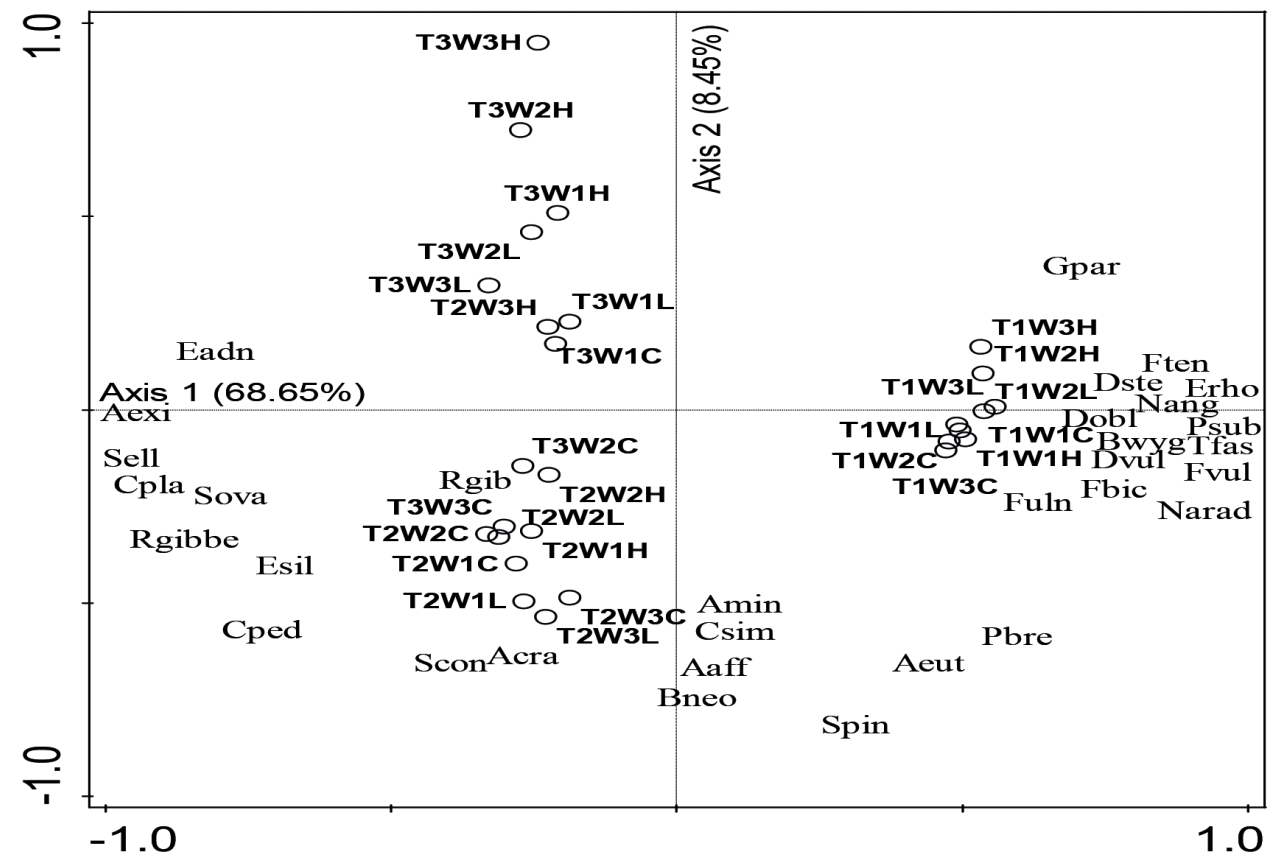

Figure 2. Principal component analysis (PCA) based on taxonomic composition of the diatom communities recorded in 9 treatments; 3 temperature levels $\left(\mathrm{T} 1=26^{\circ} \mathrm{C}, \mathrm{T} 2=28^{\circ} \mathrm{C}\right.$ and $\left.\mathrm{T} 3=30^{\circ} \mathrm{C}\right), 3$ atrazine treatments $\left(\mathrm{C}=\right.$ control with $0 \mu \mathrm{g} \cdot \mathrm{L}^{-1}, \mathrm{~L}=$ low with $15 \mu \mathrm{g} \cdot \mathrm{L}^{-1}$ and $\mathrm{H}=$ high with $200 \mathrm{\mu g}^{-1}$ ) for 3 weeks $(\mathrm{W} 1=$ Week 1, W2 = Week 2 and W3 = Week 3). See Appendix, Table A2, for diatom species codes.

a)

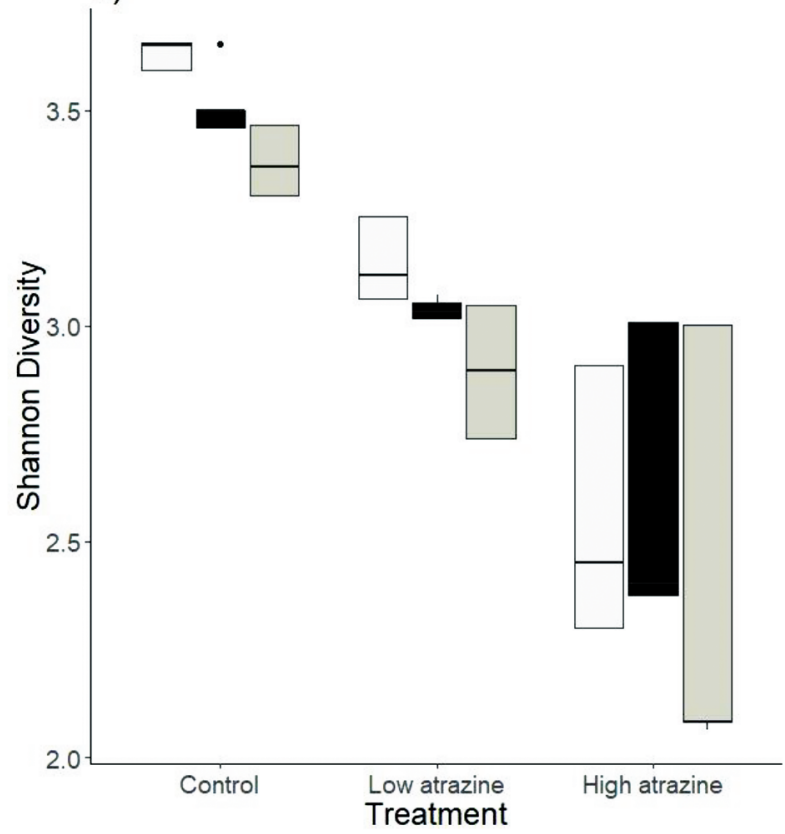

b)

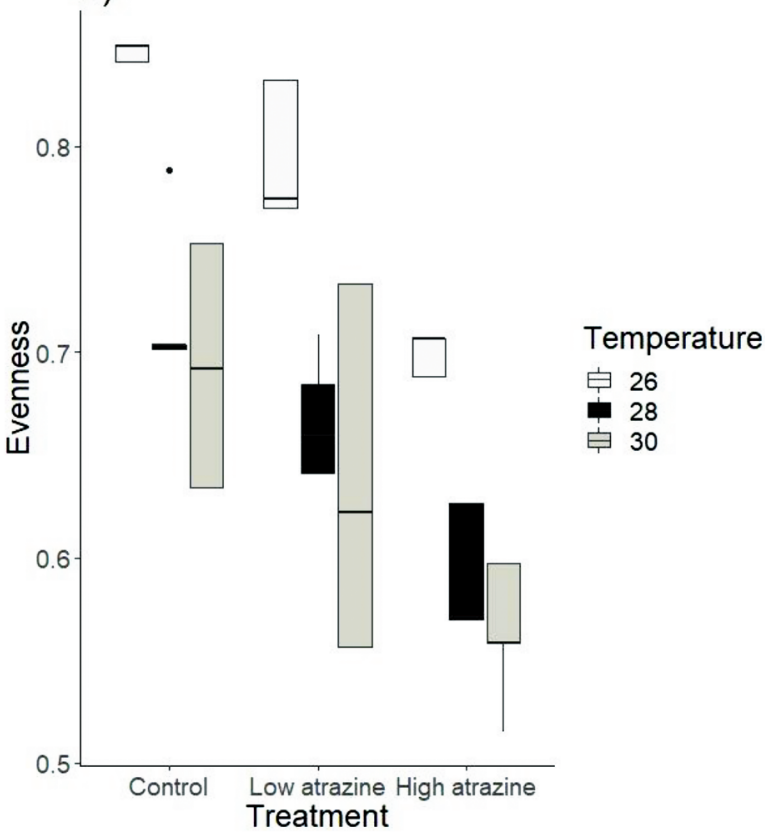

Figure 3. Plots illustrating the interactive effects of temperature and atrazine on the predicted values of (a) Shannon diversity and (b) evenness, as taken from models presented in Table A3 (Appendix).

\section{Effects of temperature and atrazine concentration on community structure and periphyton dry mass}

As is represented by the models in Table A3 (Appendix), Shannon diversity index was significantly increased by the single effect of temperature increase $(F=4.3$, d.f $=16$, $P<0.05)$ and that of atrazine concentration $(F=19.08$, d.f $=16, P<0.001)$. However, the diversity was reduced when temperatures were increased under low atrazine concentrations, and was even lower under high atrazine concentrations (Fig. 3a). Likewise, species evenness was also significantly increased by increases in both temperature $(P<0.05)$ and atrazine concentration $(P<0.001)$. The increase in temperature under low and high atrazine concentrations had a negative effect on species evenness (Fig. 3b). 
Dry mass was lower under conditions of increasing concentrations of atrazine $(F=79.08$, d.f $=16, p<0.001)$ and high at low temperatures $(F=52.5$, d.f $=16, p<0.001)$. High values of periphyton dry mass were produced at 26 and $28^{\circ} \mathrm{C}$ across the atrazine treatments (Fig. 4a, Table A3, Appendix) ( $F$ $=30.4$, d.f $=16, p<0.001$ ). For all the LMMs, random effects of the week were relatively low (range 0.002-2.87), implying no temporal trends. Richness (Fig. $4 \mathrm{~b}$ ) was significantly reduced when both temperature $(F=9.84$, d.f $=20, p<0.001)$ and atrazine $(F=152.85$, d.f $=20, p<0.001)$ increased.

\section{DISCUSSION}

\section{Effects of temperature on stream periphyton community structure.}

Taxonomic analysis revealed a shift in epilithic diatom assemblage composition with increasing temperature. Increasing temperatures in control treatments selected for Achnanthidium exiguum (Grunow) Czarnecki and Epithemia adnata (Kützing) Brébisson which have known preferences for warm waters (Lambert et al., 2016). The elimination of temperature-sensitive diatom species and subsequent succession to temperature-tolerant species is in line with the CITS hypothesis. Linear mixed effects model results showed that richness and periphyton dry mass decreased with an increase in temperature, while Shannon diversity and evenness increased. This shows that temperature plays an important role in diatom ecology, as has been suggested by several studies (Patrick, 1971; Anderson, 2000; Di Pippo et al., 2012; Larras et al., 2013; Kimberly and Salice, 2014; Mahdy et al., 2015; Lambert et al., 2016). This study, therefore, demonstrates the statistical independence of temperature, as a controlling variable, from the other dominant variables.

Temperature increases (with the exception of the control treatment at $28^{\circ} \mathrm{C}$ ) resulted in an increase in periphyton dry mass. Other studies have also made such observations; e.g., Mahdy et al. (2015) and Di Pippo et al. (2012) reported that at high temperatures $\left(30^{\circ} \mathrm{C}\right)$ diatoms increase secretion of extracellular polymeric substances (EPSs - natural polymers of high molecular weight). EPSs are important in biofilm stability, constituting $50-90 \%$ of a biofilm's organic matter; hence the increase in measured dry mass (Donlan, 2002; Evans, 2003). Various authors have associated increases in EPS production at higher temperatures with coping with increased environmental stress (Vu et al., 2009; Lambert et al., 2016; Flemming, 2016).

\section{Effects of atrazine on stream periphyton community structure}

A shift in dominance of diatom communities was observed with an increase in atrazine concentration. High atrazine treatments of $200 \mu \mathrm{g} \cdot \mathrm{L}^{-1}$ had the lowest species diversity and dry mass compared to the control and low atrazine treatments, because of photosynthetic inhibition that inhibited the accumulation of periphytic microalgal constituents and resulted in the elimination of sensitive species (Solomon et al., 1996).

Similarly to Detenbeck et al. (1996), in this study the effects of atrazine on periphyton accumulation were observed even from the lowest atrazine treatment levels of $15 \mu \mathrm{g} \cdot \mathrm{L}^{-1}$. However, other microcosm and artificial stream experiments have shown no effect up to $25 \mu \mathrm{g} \cdot \mathrm{L}^{-1}$ (Lynch et al., 1985) and the first effect at 130 to $180 \mu \mathrm{g} \cdot \mathrm{L}^{-1}$ (Jüttner et al., 1995). This could be attributed to the absence of other environmental stressors, such as temperature, that were included in this study. Relative abundance of diatoms in this study did not differ at the various atrazine levels as was also found by Giddings et al. (2005) who used similar levels of atrazine $\left(16 \mu \mathrm{g} \cdot \mathrm{L}^{-1}\right.$ and $\left.145 \mu \mathrm{g} \cdot \mathrm{L}^{-1}\right)$. This means that streams that face contamination in our region are in danger of changes in biodiversity, productivity, energy fluxes, species assemblage compositions and food web dynamics, as diatoms which are part of the primary producers of the ecosystem are being affected. The present study suggests that atrazine has the potential to impair environmental quality and ecological health of surface waters and provides evidence for the need to regulate atrazine to avoid ecological implications. a)

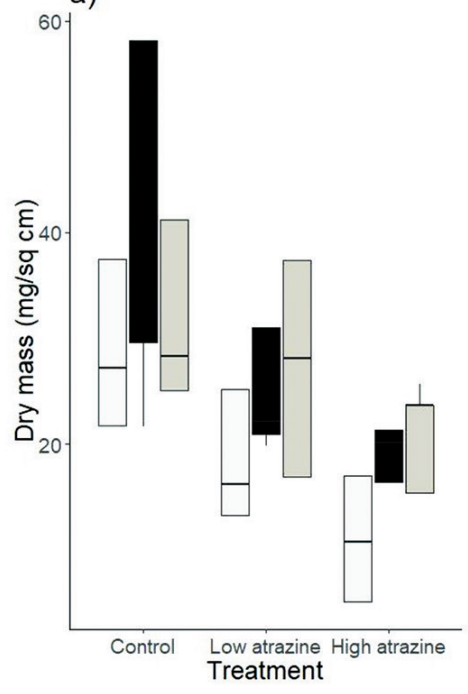

b)

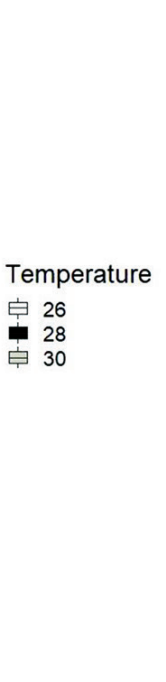

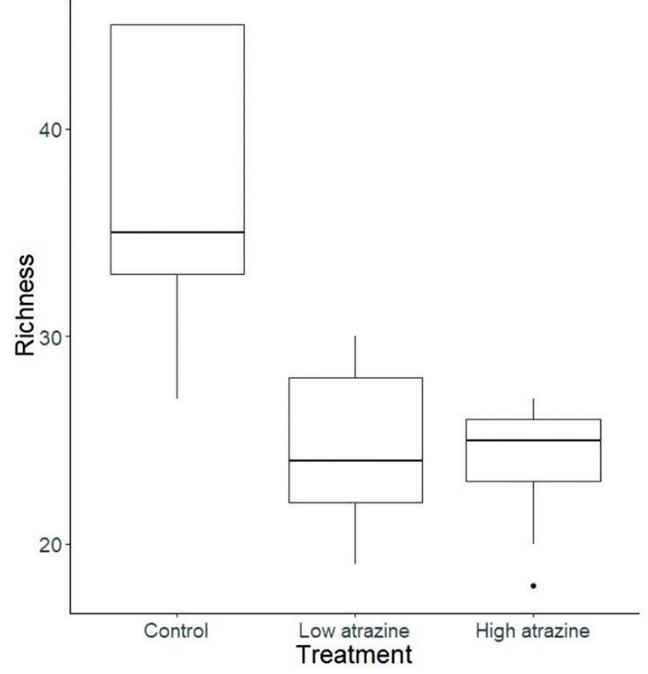

Figure 4. Plots illustrating (a) the interactive effects of temperature and atrazine on the predicted values of dry mass as taken from the model in Table A3 (Appendix) and (b) the single effect of atrazine treatments on richness 


\section{Effect of temperature on the ecotoxicity of atrazine and resulting impact on periphyton community structure and productivity}

The findings of this study regarding the main and interactive effects of atrazine and temperature are in agreement with many field observations (Wood et al., 2014; Patra et al., 2015). Kibria (2014) observed that at higher temperatures, the metabolism of aquatic organisms increases and oxygen concentration is reduced. Aerobic degradation of atrazine is therefore reduced at higher compared to lower temperatures, thereby prolonging PSII inhibition. Periphyton accumulation was significantly reduced by atrazine exposure at $26^{\circ} \mathrm{C}$ and further decline was observed in the atrazine-contaminated treatments as temperature increased, suggesting that the effect of atrazine increased with an increase in temperature. According to Kimberly and Salice (2014), changes in environmental conditions (e.g. temperature increase) can increase the vulnerability of populations or influence competition among algae. This also accounts for the changes in species diversity and species richness, as these decreased with an increase in temperature in the atrazine-contaminated sites.

Our results suggest that temperature increases the ecotoxicity of atrazine to periphyton, in line with CITS (as shown by the species diversity and richness models). Such interactions between temperature and atrazine are especially important in the face of climate change. Climate changeinduced increases in temperature are therefore set to exacerbate the effects of atrazine on periphyton. As such, climate change poses a potential risk to algae atrazine exposure, and consequently entire ecosystems as periphyton are dominant primary producers. This is a real threat in anticipated temperature increases in southern Africa (Beilfuss, 2012). To act proactively and mitigate the consequences of climate change-induced herbicide toxicity, there should be controlled use of agricultural chemicals, monitoring of atrazine levels in water bodies and ecotoxicological testing of agricultural herbicides for accurate ecological risk assessments.

\section{CONCLUSION}

An increase in temperature appears to exacerbate the toxicity of atrazine to stream periphyton. The interaction of temperature and atrazine treatment was shown to reduce species richness and dry mass. The net effect of atrazine on periphyton will therefore depend on environmental conditions such as climateinduced temperature increase. The study provides evidence for the need to regulate atrazine for better adaptation to climate change, but we acknowledge the associated challenges. Furthermore, the findings of this study attest to the potential validity of periphyton, and more specifically epilithic diatoms, as potential indicators of atrazine contamination in a changing climate. National assessment of atrazine levels in Zimbabwean water systems can improve relevance and applicability of similar studies.

\section{ACKNOWLEDGEMENTS}

This study was made possible by the provision of funds by the British Ecological Society (BES; Grant No: 4218-5112) and International Foundation for Science (IFS; Grant No: W/4848-2). We are grateful to Chinhoyi University of Technology for the laboratories used to run the experiment and for laboratory equipment for the analysis of samples. We would also like to thank Dr N Chanza, Dr JC Taylor, Tinotenda Mangadze and Admire Chanyandura for their support during the course of this study.

\section{REFERENCES}

ALOI JE (1990) A critical review of recent freshwater periphyton field methods. Can. J. Fisheries Aquat. Sci. 47 (3) 656-670. https://doi. org/10.1139/f90-073

ANDERSON NJ (2000) Miniview: Diatoms, temperature and climatic change. Eur. J. Phycol. 35 (4) 307-314. https://doi.org/10.1080/09670 260010001735911

ANSARA-ROSS T, WEPENER V, VAN DEN BRINK P and ROSS M (2012) Pesticides in South African fresh waters. Afr. J. Aquat. Sci. 37 (1) 1-16. https://doi.org/10.2989/16085914.2012.666336

BARTON K (2009) Mumin: Multi-model inference. R package version 1. 0. 0. http://r-forge. $r$-project. org/projects/mumin/.

BATES D, MAECHLER M and BOLKER B (2011) Lme4: Linear mixedeffects models using s4 classes. R package version 0.999375-39. URL: http://cran.R-project.Org/package=lme4

BAXTER L, BRAIN RA, LISSEMORE L, SOLOMON KR, HANSON ML and PROSSER RS (2016) Influence of light, nutrients, and temperature on the toxicity of atrazine to the algal species Raphidocelis subcapitata: Implications for the risk assessment of herbicides. Ecotoxicol. Environ. Saf. 132 250-259. https://doi. org/10.1016/j.ecoenv.2016.06.022

BEILFUSS R (2012) A risky climate for Southern African hydro: Assessing hydrological risks and consequences for Zambezi River basin dams. International Rivers, Berkeley, CA. 56 pp.

BERE T and CHAKANDINAKIRA AT (2018) Diatoms as indicators of anthropogenic changes in water quality in Mucheke and Shagashe Rivers, Masvingo, Zimbabwe. In: Matsumura-Tundisi T and Tundisi JG (eds) Water Resources Management. Editora Scienza, São Carlos. https://doi.org/10.26626/978-85-5953-031-5.2018C001

BERE T and MANGADZE T (2014) Diatom communities in streams draining urban areas: Community structure in relation to environmental variables. Trop. Ecol. 55 (2) 271-281.

BERE T and TUNDISI J (2011) Toxicity and sorption kinetics of dissolved cadmium and Chromium III on tropical freshwater phytoperiphyton in laboratory mesocosm experiments. Sci. Total Environ. 409 (22) 4772-4780. https://doi.org/10.1016/j. scitotenv.2011.07.055

BERE T and TUNDISI JG (2012) Effects of cadmium stress and sorption kinetics on tropical freshwater periphytic communities in indoor mesocosm experiments. Sci. Total Environ. 432 103-112. https://doi.org/10.1016/j.scitotenv.2012.05.084

BETHSASS J and COLANGELO A (2006) European Union bans atrazine, while the United States negotiates continued use. Int. J. Occup. Environ. Health 12 (3) 260-267. https://doi.org/10.1179/ oeh.2006.12.3.260

BIGGS B and KILROY C (2000) Stream Periphyton Monitoring Manual. New Zealand Ministry for the Environment, New Zealand.

BLANCK H (2002) A critical review of procedures and approaches used for assessing pollution-induced community tolerance (pict) in biotic communities. Hum. Ecol. Risk Assess. 8 (5) 1003-1034. https://doi.org/10.1080/1080-700291905792

BOONE MD and BRIDGES CM (1999) The effect of temperature on the potency of carbaryl for survival of tadpoles of the green frog (Rana clamitans). Environ. Toxicol. Chem. 18 (7) 1482-1484. https://doi.org/10.1002/etc.5620180720

BOZINOVIC F and PÖRTNER HO (2015) Physiological ecology meets climate change. Ecol. Evol. 5 (5) 1025-1030. https://doi.org/10.1002/ ece 3.1403

BRAIN RA, HOBERG J, HOSMER AJ and WALL SB (2012) Influence of light intensity on the toxicity of atrazine to the submerged freshwater aquatic macrophyte Elodea canadensis. Ecotoxicol. Environ. Saf. 79 55-61. https://doi.org/10.1016/j.ecoenv.2011.12.001

BROCKWAY DL, SMITH PD and STANCIL FE (1984) Fate and effects of atrazine in small aquatic microcosms. Bull. Environ. Contam. Toxicol. 32 (1) 345-353. https://doi.org/10.1007/BF01607508 
BROOMHALL S (2002) The effects of endosulfan and variable water temperature on survivorship and subsequent vulnerability to predation in Litoria citropa tadpoles. Aquat. Toxicol. 61 (3-4) 243-250. https://doi.org/10.1016/S0166-445X(02)00061-9

CAPKIN E, ALTINOK I and KARAHAN S (2006) Water quality and fish size affect toxicity of endosulfan, an organochlorine pesticide, to rainbow trout. Chemosphere 64 (10) 1793-1800. https://doi. org/10.1016/j.chemosphere.2005.12.050

CROSSLAND NO and LA POINT TW (1992) The design of mesocosm experiments. Environ. Toxicol. Chem. 11 (1) 1-4. https://doi. org/10.1002/etc.5620110101

DAAM MA and VAN DEN BRINK PJ (2010) Implications of differences between temperate and tropical freshwater ecosystems for the ecological risk assessment of pesticides. Ecotoxicology 19 (1) 24-37. https://doi.org/10.1007/s10646-009-0402-6

DALLAS H (2008) Water temperature and riverine ecosystems: An overview of knowledge and approaches for assessing biotic responses, with special reference to South Africa. Water SA 34 (3) 393-404. https://doi.org/10.4314/wsa.v34i3.180634

DARON J (2014) Regional climate messages: Southern Africa. Scientific report from the CARIAA Adaptation at Scale in SemiArid Regions (ASSAR) project, December 2014.

DETENBECK NE, HERMANUTZ R, ALLEN K and SWIFT MC (1996) Fate and effects of the herbicide atrazine in flow-through wetland mesocosms. Environ. Toxicol. Chem. 15 (6) 937-946. https://doi.org/10.1002/etc.5620150616

DI PIPPO F, ELLWOOD NTW, GUZZON A, SILIATO L, MICHELETTI E, DE PHILIPPIS R and ALBERTANO PB (2012) Effect of light and temperature on biomass, photosynthesis and capsular polysaccharides in cultured phototrophic biofilms. J. Appl. Phycol. 24 (2) 211-220. https://doi.org/10.1007/ s10811-011-9669-0

DONLAN RM (2002) Biofilms: Microbial life on surfaces. Emerg. Infect. Dis. 8 (9). https://doi.org/10.3201/eid0809.020063

EVANS LV (2003) Biofilms: Recent Advances in their Study and Control. CRC Press, Boca Raton.

FLEMMING H-C (2016) Eps-then and now. Microorganisms 4 (4) 41. https://doi.org/10.3390/microorganisms4040041

GAUNT P and BARKER SA (2000) Matrix solid phase dispersion extraction of triazines from catfish tissues; examination of the effects of temperature and dissolved oxygen on the toxicity of atrazine. Int. J. Environ. Pollut. 13 (1-6) 284-312. https://doi. org/10.1504/IJEP.2000.002320

GIDDINGS JM, ANDERSON TA, HALL LW JR, KENDALL RJ, RICHARDS RP, SOLOMON KR, and WILLIAMS WM (2005) A Probabilistic aquatic ecological risk assessment of atrazine in North American surface waters. SETAC, Pensacola, FL, USA.

GOLD C, FEURTET-MAZEL A, COSTE M and BOUDOU A (2003) Effects of cadmium stress on periphytic diatom communities in indoor artificial streams. Freshwater Biol. 48 (2) 316-328. https:// doi.org/10.1046/j.1365-2427.2003.00980.x

GUASCH H, IVORRA N, LEHMANN V, PAULSSON M, REAL $M$ and SABATER S (1998) Community composition and sensitivity of periphyton to atrazine in flowing waters: The role of environmental factors. J. Appl. Phycol. 10 (2) 203-213. https://doi. org/10.1023/A:1008035212208

HAMMER O, HARPER D and RYAN P (2001) Past (paleontological statistics) version 3.14. Software package for education and data analysis. Paleontol. Electrón. 4 (1) 9 pp.

HANSSON L (1992) Factors regulating periphytic algal biomass. Limnol. Oceanogr. 37 (2) 322-328. https://doi.org/10.4319/ lo.1992.37.2.0322

HOOPER MJ, ANKLEY GT, CRISTOL DA, MARYOUNG LA, NOYES PD and PINKERTON KE (2013) Interactions between chemical and climate stressors: A role for mechanistic toxicology in assessing climate change risks. Environ. Toxicol. Chem. 32 (1) 32-48. https:// doi.org/10.1002/etc.2043

JÜTTNER I, PEITHER A, LAY J, KETTRUP A and ORMEROD S (1995) An outdoor mesocosm study to assess ecotoxicological effects of atrazine on a natural plankton community. Arch. Environ. Contam. Toxicol. 29 (4) 435-441. https://doi.org/10.1007/ BF00208371
KESARI R and GUPTA V (1998) A simple method for the spectrophotometric determination of atrazine using p-aminoacetophenone and its application in environmental and biological samples. Talanta 47 (5) 1085-1092. https://doi. org/10.1016/S0039-9140(98)00168-4

KIBRIA G (2014) Climate change and chemical contaminants. URL: https://www.researchgate.net/publication/261216780_Climate_ Change_and_Chemical_Contaminants

KILHAM SS, THERIOT EC and FRITZ SC (1996) Linking planktonic diatoms and climate change in the large lakes of the yellowstone ecosystem using resource theory. Limnol. Oceanogr. 41 (5) 1052 1062. https://doi.org/10.4319/lo.1996.41.5.1052

KIMBERLY DA and SALICE CJ (2014) Complex interactions between climate change and toxicants: Evidence that temperature variability increases sensitivity to cadmium. Ecotoxicology 23 (5) 809-817. https://doi.org/10.1007/s10646-014-1221-y

KOSINSKI RJ and MERKLE MG (1984) The effect of four terrestrial herbicides on the productivity of artificial stream algal communities. J. Environ. Qual. 13 (1) 75-82. https://doi. org/10.2134/jeq1984.00472425001300010014x

LAMBERT AS, DABRIN A, MORIN S, GAHOU J, FOULQUIER A, COQUERY M and PESCE S (2016) Temperature modulates phototrophic periphyton response to chronic copper exposure. Environ. Pollut. 208 821-829. https://doi.org/10.1016/j. envpol.2015.11.004

LANDIS WG, ROHR JR, MOE SJ, BALBUS JM, CLEMENTS W, FRITZ A, HELM R, HICKEY C, HOOPER M and STAHL RG (2014) Global climate change and contaminants, a call to arms not yet heard? Integr. Environ. Assess. Manage. 10 (4) 483-484. https:// doi.org/10.1002/ieam.1568

LARRAS F, LAMBERT A-S, PESCE S, RIMET F, BOUCHEZ A and MONTUELLE B (2013) The effect of temperature and a herbicide mixture on freshwater periphytic algae. Ecotoxicol. Environ. Saf. 98 162-170. https://doi.org/10.1016/j.ecoenv.2013.09.007

LAVIALE M, PRYGIEL J and CRÉACH A (2010) Light modulated toxicity of isoproturon toward natural stream periphyton photosynthesis: A comparison between constant and dynamic light conditions. Aquat. Toxicol. 97 (4) 334-342. https://doi. org/10.1016/j.aquatox.2010.01.004

LYDY MJ, BELDEN J and TERNES M (1999) Effects of temperature on the toxicity of m-parathion, chlorpyrifos, and pentachlorobenzene to Chironomus tentans. Arch. Environ. Contam. Toxicol. 37 (4) 542-547. https://doi.org/10.1007/s002449900550

LYNCH TR, JOHNSON HE and ADAMS WJ (1985) Impact of atrazine and hexachlorobiphenyl on the structure and function of model stream ecosystems. Environ. Toxicol. Chem. 4 (3) 399-413. https:// doi.org/10.1002/etc.5620040315

MAGADZA C (2010) Environmental state of Lake Kariba and Zambezi River valley: Lessons learned and not learned. Lakes Reservoirs Res. Manage. 15 (3) 167-192. https://doi. org/10.1111/j.1440-1770.2010.00438.x

MAHDY A, HILT S, FILIZ N, BEKLIOĞLU M, HEJZLAR J, ÖZKUNDAKCI D, PAPASTERGIADOU E, SCHARFENBERGER U, ŠORF M and STEFANIDIS K (2015) Effects of water temperature on summer periphyton biomass in shallow lakes: A pan-European mesocosm experiment. Aquat. Sci. 77 (3) 499-510. https://doi. org/10.1007/s00027-015-0394-7

MINISTRY OF ENVIRONMENT AND NATURAL RESOURCES MANAGEMENT (2013) Zimbabwe National Climate Change Response Strategy (first draft). Harare, Zimbabwe: Government of Zimbabwe.

MUPAKO K (2016) Personal communication, 15 January 2016. Sales manager, Agricura Chinhoyi Branch, 137, Midway St, Chinhoyi, Zimbabwe.

NICHOLS HW (1973) Growth media-freshwater. In: Handbook of Phycological Methods: Culture Methods and Growth Measurements. 7-24.

NYHOLM N and KÄLLQVIST T (1989) Methods for growth inhibition toxicity tests with freshwater algae. Environ. Toxicol. Chem. 8 (8) 689-703. https://doi.org/10.1002/etc.5620080807

ODUM EP (1984) The mesocosm. BioScience 34 (9) 558-562. https:// doi.org/10.2307/1309598 
OSIBANJO O, BOUWMAN H, BASHIR N, OKOND'AHOKA J, CHOONG KWET YVE R and ONYOYO H (2002) Regionally based assessment of persistent toxic substances. Sub-saharan Africa regional report. UNEP Chemicals, Geneva.

PAPPAS JL and STOERMER EF (1996) Quantitative method for determining a representative algal sample count 1. J. Phycol. 32 (4) 693-696. https://doi.org/10.1111/j.0022-3646.1996.00693.x

PATRA RW, CHAPMAN JC, LIM RP, GEHRKE PC and SUNDERAM RM (2015) Interactions between water temperature and contaminant toxicity to freshwater fish. Environ. Toxicol. Chem. $\mathbf{3 4}$ (8) 1809-1817. https://doi.org/10.1002/etc.2990

PATRICK R (1971) The effects of increasing light and temperature on the structure of diatom communities. Limnol. Oceanogr. 16 (2) 405-421. https://doi.org/10.4319/lo.1971.16.2.0405

PICK FE, VAN DYK LP and BOTHA E (1992) Atrazine in ground and surface water in maize production areas of the Transvaal, South Africa. Chemosphere 25 (3) 335-341. https://doi. org/10.1016/0045-6535(92) $90550-B$

PLUMLEY FG and DAVIS DE (1980) The effects of a photosynthesis inhibitor atrazine, on salt marsh edaphic algae, in culture, microecosystems, and in the field. Estuaries 3 (4) 271-277. https:// doi.org/10.2307/1352082

R CORE TEAM (2016) R: A language and environment for statistical computing. Vienna, Austria. Retrieved from https://www.Rproject.org/

RELYEA RA (2005) The impact of insecticides and herbicides on the biodiversity and productivity of aquatic communities. Ecol. Appl. 15 (2) 618-627. https://doi.org/10.1890/03-5342

SHIMABUKURO RH and SWANSON HR (1969) Atrazine metabolism, selectivity, and mode of action. J. Agric. Food Chem. 17 (2) 199-205. https://doi.org/10.1021/jf60162a044

SILBERGELD EK (1973) Dieldrin. Effects of chronic sublethal exposure on adaptation to thermal stress in fresh water fish. Environ. Sci. Technol. 7 (9) 846-849. https://doi.org/10.1021/ es60081a010
SOLOMON KR, BAKER DB, RICHARDS RP, DIXON KR, KLAINE SI, LA POINT TW, KENDALL RJ, WEISSKOPF CP, GIDDINGS JM and GIESY JP (1996) Ecological risk assessment of atrazine in North American surface waters. Environ. Toxicol. Chem. 15 (1) 31-76. https://doi.org/10.1002/etc.5620150105

TAYLOR JC, HARDING WR and ARCHIBALD C (2007) An illustrated guide to some common diatom species from South Africa. WRC Report No. TT 282/07. Water Research Commission, Pretoria.

VILLENEUVE A, HUMBERT J and LARROUDÉ S (2011) Herbicide Contamination of Freshwater Ecosystems: Impact on Microbial Communities: IntechOpen.URL: https://www.intechopen. com/books/pesticides-formulations-effects-fate/herbicidecontamination-of-freshwater-ecosystems-impact-on-microbialcommunities.

VU B, CHEN M, CRAWFORD RJ and IVANOVA EP (2009) Bacterial extracellular polysaccharides involved in biofilm formation. Molecules 14 (7) 2535-2554. https://doi.org/10.3390/ molecules 14072535

WOOD RJ, MITROVIC SM and KEFFORD BJ (2014) Determining the relative sensitivity of benthic diatoms to atrazine using rapid toxicity testing: A novel method. Sci. Total Environ. 485 421-427. https://doi.org/10.1016/j.scitotenv.2014.03.115

WOOD RJ, MITROVIC SM, LIM RP and KEFFORD BJ (2016) The influence of reduced light intensity on the response of benthic diatoms to herbicide exposure. Environ. Toxicol. Chem. 35 (9) 2252-2260. doi: 10.1002/etc.3379 https://doi.org/10.1002/etc.3379

YOKLEY RA and CHEUNG MW (2000) Analytical method for the determination of atrazine and its dealkylated chlorotriazine metabolites in water using gas chromatography/mass selective detection. J. Agric. Food Chem. 48 (10) 4500-4507. https://doi. org/10.1021/jf991100v

Table A1. Duplicate water analysis of nominal and measured atrazine concentrations for each test treatment, taken during the experiment. $\mathrm{LOD}$ is $0.05 \mathrm{ng}$ and LOQ is $0.1 \mu \mathrm{g} \cdot \mathrm{L}^{-1}$

\begin{tabular}{lccc}
\hline $\begin{array}{c}\text { Temperature } \\
\left({ }^{\circ} \mathrm{C}\right)\end{array}$ & $\begin{array}{c}\text { Duration } \\
(\text { week })\end{array}$ & $\begin{array}{c}\text { Nominal } \\
\text { concentration } \\
\left(\mu \mathrm{g} \cdot \mathrm{L}^{-1}\right)\end{array}$ & $\begin{array}{c}\text { Actual } \\
\text { concentration } \\
\left(\boldsymbol{\mu} \cdot \mathrm{L}^{-1}\right)\end{array}$ \\
\hline 26 & 1 & 15 & 14 \\
& 2 & 200 & 189 \\
& & 15 & 14 \\
& 3 & 200 & 184 \\
& & 15 & 13 \\
28 & 1 & 15 & 178 \\
\hline 30 & 200 & 15 \\
& 2 & 15 & 190 \\
& & 200 & 14 \\
& 3 & 15 & 183 \\
& & 200 & 13 \\
& 1 & 15 & 18 \\
\hline & & 200 & 15 \\
& 2 & 15 & 188 \\
& & 200 & 185 \\
& 3 & 15 & 13 \\
\hline
\end{tabular}


Table A2. Diatom species relative abundances and codes used in the principle components analysis. ${ }^{*}=0-5 \%,{ }^{* *}=5-10 \%$, ${ }^{* * *}=>10 \%$. $1-3=26^{\circ} \mathrm{C}$ for control, low and high atrazine treatments respectively; $4-6=28^{\circ} \mathrm{C}$ for control, low and high atrazine treatments respectively and $7-9=30^{\circ} \mathrm{C}$ for control, low and high atrazine treatments respectively.

\begin{tabular}{|c|c|c|c|c|c|c|c|c|c|c|}
\hline Species & Codes & 1 & 2 & 3 & 4 & 5 & 6 & 7 & 8 & 9 \\
\hline Achnanthidium affine (Grunow) Czarnecki & Aaff & ** & * & * & * & * & ** & * & * & ** \\
\hline Achnanthidium crassum (Hustedt) Potapova \& Ponader & Acra & * & * & * & * & * & * & * & * & * \\
\hline Achnanthidium eutrophilum (Lange-Bertalot) Lange-Bertalot & Aeut & * & * & * & * & * & * & * & * & * \\
\hline Achnanthidium exiguum (Grunow) Czarnecki & Aexi & * & * & * & ** & * & * & ** & ** & *** \\
\hline Achnanthidium minutissimum (Kützing) Czarnecki & Amin & ** & * & * & * & ** & * & * & * & * \\
\hline Achnanthes oblongella Oestrup & Aobl & * & * & * & * & * & * & * & * & * \\
\hline Amphipleura pellucida (Kützing) Kützing & Apel & * & * & * & * & * & * & * & * & * \\
\hline Amphora copulate (Kützing) Schoeman \& Archibald & Acop & * & * & * & * & * & * & * & * & * \\
\hline Amphora ovalis (Kützing) Kützing & Aova & * & $*$ & * & * & * & * & * & * & * \\
\hline Amphora pediculus (Kützing) Grunow & Aped & * & * & * & * & * & * & * & * & * \\
\hline Amphora veneta Kützing & Aven & * & * & * & * & * & * & * & * & * \\
\hline Asterionella Formosa Hassal & Afor & * & * & $*$ & * & * & * & * & * & * \\
\hline Aulacoseira granulate (Ehrenberg) Simonsen & Agra & * & * & * & * & $*$ & * & * & * & * \\
\hline Brachysira neoexilis (Grunow) DG Mann & Bneo & ** & $*$ & $*$ & * & * & * & * & * & * \\
\hline Brachysira wygaschii Lange-Bertalot & Bwyg & ** & ** & ** & * & $*$ & * & $*$ & * & * \\
\hline Caloneisa equatorialis Hustedt & Cacq & * & $*$ & * & * & * & * & * & * & * \\
\hline Caloneis bacillum (Grunow) Cleve & Cbac & * & $*$ & $*$ & * & $*$ & * & * & $*$ & * \\
\hline Cocconeis pediculus Ehrenberg & Cped & * & $*$ & * & * & $*$ & * & $*$ & * & * \\
\hline Cocconeis placentula Ehrenberg & Cpla & * & $*$ & $*$ & $* *$ & ** & * & * & $*$ & * \\
\hline Craticula ambigua (Ehrenberg) DG Mann & Camb & * & * & * & * & * & * & * & $*$ & * \\
\hline Craticula buderi (Hustedt) & Cbud & * & * & * & * & * & * & * & * & * \\
\hline Cyclotella ocellata Pantocsek & Coce & * & * & * & * & * & * & * & * & * \\
\hline $\begin{array}{l}\text { Cyclostephanos invisitatus (Hohn \& Hellerman)Theriot, Stoermer \& } \\
\text { Håkansson }\end{array}$ & Cinv & * & * & * & * & * & * & * & * & * \\
\hline Cyclotella meneghiniana Kützing & Cmen & * & * & * & * & * & * & * & * & * \\
\hline Cymatopleura solea (Brébisson) W Smith & Csol & * & * & * & * & * & * & * & * & * \\
\hline Cymbella simonsenii Krammer & Csim & * & * & * & * & * & * & * & * & * \\
\hline Denticula subtilis Grunow & Dsub & * & * & $*$ & * & * & * & * & * & * \\
\hline Diadesmis confervacea (Kützing) DG Mann & Dcon & * & * & $*$ & * & * & * & * & * & * \\
\hline Diadesmis contenta (Grunow in Van Heurk) DG Mann & Dcont & * & * & * & * & * & * & * & * & * \\
\hline Diatoma vulgaris Bory & Dvul & * & ** & ** & * & * & * & * & * & * \\
\hline Diploneis elliptica (Kützing) Cleve & Dell & * & * & * & * & * & * & * & * & * \\
\hline Diploneis oblongella (Naegeli) Cleve-Euler & Dobl & * & * & ** & * & * & * & * & * & * \\
\hline Diploneis subovalis Cleve & Dsubo & * & * & * & * & * & * & * & * & * \\
\hline Discostella pseudostelligera (Hustedt) Houk \& Klee & Dpse & * & $*$ & * & * & * & * & * & * & * \\
\hline Discostella stelligera (Hustedt) Houk \& Klee & Dste & $*$ & * & * & * & * & * & * & $*$ & * \\
\hline Encyonema mesianum (Cholnoky) DG Mann & Emes & * & * & * & * & * & * & * & * & * \\
\hline Encyonema minutum (Hilse) DG Mann & Emin & * & * & $*$ & * & * & * & * & * & * \\
\hline Encyonema silesiacum (Bleisch) DG Mann & Esil & * & * & * & $*$ & * & * & * & * & * \\
\hline Encyonopsis krammeri Reichardt & Ekra & * & * & * & * & $*$ & * & $*$ & * & * \\
\hline Epithemia adnata (Kützing) Brébisson & Eadn & * & * & * & * & $*$ & * & $*$ & $*$ & $* *$ \\
\hline Eunotia exigua (Brébisson) Rabenhorst & Eexi & * & $*$ & * & * & * & * & * & * & * \\
\hline Eunotia flexuosa (Brébisson) Kützing & Efle & * & * & * & * & * & * & * & $*$ & * \\
\hline Eunotia formica Ehrenberg & Efor & $*$ & $*$ & $*$ & $*$ & $*$ & * & * & $*$ & * \\
\hline Eunotia minor (Kützing) Grunow & Emino & * & * & * & * & $*$ & * & * & $*$ & * \\
\hline Eunotia pectinalis var. undulate (Ralfs) Rabenhorst & Epec & * & * & $*$ & * & * & * & * & * & * \\
\hline Eunotia rhomboidea Hustedt & Erho & * & * & * & * & * & * & * & * & * \\
\hline Fallacia monoculata (Hustedt) DG Mann & Fmon & * & $*$ & * & * & * & * & * & * & * \\
\hline Fragilaria biceps (Kützing) Lange-Bertalot & Fbic & * & $*$ & * & * & * & * & * & * & * \\
\hline Fragilaria capucina Desmazières & Fcap & * & * & * & * & $*$ & * & * & * & * \\
\hline Fragilaria nanana Lange-Bertalot & Fnan & * & $*$ & * & * & $*$ & * & * & * & * \\
\hline Fragilaria tenera (WM Smith) Lange-Bertalot & Ften & * & * & * & * & * & * & * & * & * \\
\hline Fragilaria ulna (Nitzsch) Lange-Bertalot & Fuln & * & * & * & * & * & * & * & * & * \\
\hline Frustulia magaliesmontana Cholnoky & Fmag & * & * & * & * & * & * & * & * & * \\
\hline Frustulia vulgaris (Thwaites) De Toni & Fvul & * & * & $*$ & * & $*$ & * & * & * & * \\
\hline
\end{tabular}


Table A2. (cont.).

\begin{tabular}{|c|c|c|c|c|c|c|c|c|c|c|}
\hline Species & Codes & 1 & 2 & 3 & 4 & 5 & 6 & 7 & 8 & 9 \\
\hline Gomphonema affine Kützing & Gaff & * & * & * & * & * & * & * & * & * \\
\hline Gomphonema exilissimum Lange-Bertalot \& Reichardt & Gexi & * & * & * & * & * & * & * & * & * \\
\hline Gomphonema insigne Gregory & Gins & * & * & * & * & * & * & * & * & * \\
\hline Gomphonema italicum Kützing & Gita & * & * & * & * & * & * & * & * & * \\
\hline Gomphonema laticollum Reichart & Glat & * & * & $*$ & * & * & * & * & * & * \\
\hline Gomphonema minutum (Agardh) Agardh & Gmin & * & * & * & * & * & * & * & * & * \\
\hline Gomphonema parvulum ( Kützing) Kützing sensustricto & Gpar & * & * & * & * & * & * & * & * & * \\
\hline Gomphonema pumilum var. Rigidum Reichardt \& Lange-Bertalot & Gpum & * & * & * & * & * & * & * & * & * \\
\hline Gyrosigma attenuatum (Kützing) Cleve & Gatt & * & * & * & * & * & * & * & * & * \\
\hline Hippodonta capitata (Ehrenberg) Lange-Bertalot, Metzeltin \&Witkowski & Hcap & * & * & * & * & * & * & * & * & * \\
\hline Luticola kotschyi (Grunow) & Lkot & * & * & * & * & * & * & * & $*$ & * \\
\hline Mastogloia dansei (Thwaites) Thwaites & Mdan & * & * & $*$ & * & * & * & * & * & * \\
\hline Mastogloia elliptica (Agardh) Cleve & Mell & * & * & * & * & * & * & * & * & * \\
\hline Mastogloia smithii Thwaites & Msmi & * & $*$ & $*$ & * & * & $*$ & * & * & * \\
\hline Melosira varians Agardh & Mvar & * & * & * & * & * & * & * & * & * \\
\hline Navicula angusta Grunow & Nang & ** & * & * & * & * & * & * & * & * \\
\hline Navicula cryptocephala Kützing & Ncry & * & * & * & * & * & * & * & * & * \\
\hline Navicula heimansioides Lange-Bertalot & Nhei & * & * & * & * & * & * & * & * & * \\
\hline Navicula radiosa Kützing & Narad & ** & * & * & * & * & * & * & * & * \\
\hline Navicula ranomafenensis (Manguin) Metzeltin \& Lange-Bertalot & Nran & * & * & * & * & * & * & * & * & * \\
\hline Neidium affine (Ehrenberg) Pfitzer & Naff & * & * & * & * & * & * & * & * & * \\
\hline Neidium productum (W Smith) Cleve & Npro & * & * & * & * & * & * & * & $*$ & * \\
\hline Nitzschia capitellata Hustedt & Ncap & * & * & * & * & * & * & * & * & * \\
\hline Nitzschia dissipata (Kützing) Grunow & Ndis & * & * & * & * & * & * & * & $*$ & $*$ \\
\hline Nitzschia filiformis (W Smith) Van Heurk & Nifil & * & * & * & * & * & * & * & * & * \\
\hline Nitzschia heufleriana Grunow & Nheu & * & * & * & * & * & * & * & * & * \\
\hline Nitzschia linearis (Agardh) W Smith & Nlin & * & * & * & * & * & * & * & * & * \\
\hline Nitzschia nana Grunow & Nnan & * & * & * & * & * & * & * & $*$ & $*$ \\
\hline Nitzschia palea (Kützing) W Smith & Npal & * & * & * & * & * & * & * & * & * \\
\hline Nitzschia radicula Hustedt & Nrad & * & * & * & $*$ & * & * & * & * & * \\
\hline Nitzschia recta Hantzsch & Nrec & * & * & * & * & * & * & * & * & * \\
\hline Nitzschia sigma (Kützing) W Smith & Nsig & * & * & * & * & * & * & $*$ & * & * \\
\hline Nitzschia sinuata var. delognei (Grunow) Lange-Bertalot & Nsin & * & * & * & * & * & * & * & * & * \\
\hline Nitzschia valdecostata Lange-Bertalot \& Simonsen & Nval & * & * & * & * & * & * & * & * & * \\
\hline Nitzschia pusilla Grunow & Npus & * & * & * & * & * & * & * & $*$ & * \\
\hline Pinnularia acrosphaeria W Smith & Pacr & * & * & * & * & * & * & * & $*$ & * \\
\hline Pinnularia borealis Ehrenberg sensulato & Pbor & * & * & * & * & * & * & * & $*$ & * \\
\hline Pinnularia subcapitata Gregory & Psub & ** & ** & $*$ & * & * & * & $*$ & $*$ & * \\
\hline Pinnularia viridiformis Krammer & Pvir & * & * & * & * & * & * & * & * & * \\
\hline Planothidium frequentissimum (Lange-Bertalot) Round \& Bukhityarova & Pfre & * & * & ** & * & * & * & * & * & * \\
\hline Planothidium rostratum (Oestrup) Round \& Bukhityarova & Pros & * & * & * & * & * & * & * & * & * \\
\hline Pseudostaurosira brevistriata (Grunow in van Heurk) Williams \& Round & Pbre & $* *$ & ** & ** & * & $* *$ & * & $* *$ & * & $* *$ \\
\hline Rhopalodia gibba (Ehrenberg) O Müller & Rgib & * & * & * & * & * & * & * & * & * \\
\hline Rhopalodia gibberula (Ehrenberg) O Müller & Rgibbe & * & * & * & * & * & * & * & * & * \\
\hline Sellaphora pupula (Kützing) Mereschkowsky sensulato & Spup & * & * & * & * & * & * & * & * & * \\
\hline Stauroneis anceps Ehrenberg sensulato & Sanc & * & * & * & * & * & * & * & * & * \\
\hline Staurosira elliptica (Schumann) Williams \& Round & Sell & * & * & * & $* *$ & * & $* *$ & ** & $* *$ & ** \\
\hline Staurosirella pinnata (Ehrenberg) Williams \& Round & Spin & ** & * & * & ** & $* * *$ & $* * *$ & * & * & * \\
\hline Staurosira construens Ehrenberg & Scon & * & * & * & $* * *$ & *** & $* * *$ & $* * *$ & ** & * \\
\hline Surirella ovalis Brébisson & Sova & * & * & * & * & * & * & * & * & ** \\
\hline Tabulariafasciculata (Agardh) Williams \& Round & Tfas & * & * & * & * & * & * & * & * & * \\
\hline Tryblionella calida (Grunow) DG Mann & Tcal & * & * & * & * & * & * & * & * & * \\
\hline
\end{tabular}


Table A3. Information of the different linear mixed-effects model of the response variables (species diversity, richness, evenness and dry mass) on temperature and atrazine treatment (predictor variables). $\mathrm{T} 2=28^{\circ} \mathrm{C}$ and $\mathrm{T} 3=30^{\circ} \mathrm{C}$.

\begin{tabular}{|c|c|c|c|c|c|c|}
\hline Model & Variable & Value & \pm S.E & DF & $t$-value & $P$ value \\
\hline \multirow[t]{9}{*}{ Shannon } & Intercept & 1.63 & 0.35 & 886 & 4.7 & $<0.001$ \\
\hline & $\mathrm{T} 2$ & 2.04 & 0.26 & 16 & 7.96 & $<0.001$ \\
\hline & $\mathrm{T} 3$ & 1.65 & 0.19 & 16 & 8.65 & $<0.001$ \\
\hline & Low atrazine & 0.8 & 0.17 & 16 & 4.6 & $<0.001$ \\
\hline & High atrazine & 0.8 & 0.17 & 16 & 4.59 & $<0.001$ \\
\hline & T2: Low atrazine & -1.63 & 0.3 & 16 & -5.45 & $<0.001$ \\
\hline & T2: High atrazine & -2.11 & 0.28 & 16 & -7.46 & $<0.001$ \\
\hline & T3: Low atrazine & -2.22 & 0.23 & 16 & -9.69 & $<0.001$ \\
\hline & T3: High atrazine & -1.65 & 0.25 & 16 & -6.52 & $<0.001$ \\
\hline \multirow[t]{5}{*}{ Richness } & Intercept & 39.7 & 2.2 & 886 & 18.01 & 0.00 \\
\hline & $\mathrm{T} 2$ & -0.44 & 0.9 & 20 & -0.49 & 0.63 \\
\hline & T3 & -3.67 & 0.9 & 20 & -4.06 & 0.0006 \\
\hline & Low atrazine & -12.56 & 0.9 & 20 & -13.91 & 0.00 \\
\hline & High atrazine & -14.55 & 0.9 & 20 & -16.13 & 0.00 \\
\hline \multirow[t]{9}{*}{ Evenness } & Intercept & 0.52 & 0.03 & 886 & 18.79 & 0.00 \\
\hline & $\mathrm{T} 2$ & 0.5 & 0.05 & 16 & 10.33 & 0.00 \\
\hline & $\mathrm{T} 3$ & 0.24 & 0.03 & 16 & 7.13 & 0.00 \\
\hline & Low atrazine & 0.12 & 0.03 & 16 & 3.71 & 0.002 \\
\hline & High atrazine & 0.13 & 0.03 & 16 & 4.01 & 0.001 \\
\hline & T2: Low atrazine & -0.35 & 0.06 & 16 & -6.008 & 0.00 \\
\hline & T2: High atrazine & -0.66 & -0.054 & 16 & 12.25 & 0.00 \\
\hline & T3: Low atrazine & -0.41 & 0.042 & 16 & -9.6 & 0.00 \\
\hline & T3 High atrazine & -0.45 & 0.05 & 16 & -9.35 & 0.00 \\
\hline \multirow[t]{9}{*}{ Dry mass } & Intercept & 26.73 & 2.02 & 886 & 13.25 & 0.00 \\
\hline & $\mathrm{T} 2$ & -2.92 & 1.98 & 16 & -1.48 & 0.16 \\
\hline & T3 & -8.35 & 1.45 & 16 & -5.75 & 0.00 \\
\hline & Low atrazine & -14.52 & 1.32 & 16 & -10.99 & 0.00 \\
\hline & High atrazine & -17.58 & 1.32 & 16 & -13.31 & 0.00 \\
\hline & T2: Low atrazine & 13.81 & 2.29 & 16 & 6.04 & 0.00 \\
\hline & T2: High atrazine & 10.09 & 2.17 & 16 & 4.64 & 0.0003 \\
\hline & T3: Low atrazine & 18.97 & 1.74 & 16 & 10.90 & 0.00 \\
\hline & T3: High atrazine & 11.27 & 1.93 & 16 & 5.85 & 0.00 \\
\hline
\end{tabular}

